\title{
Y-TZP の低温熱処理による熱劣化深さ†
}

四方 良 * $^{*}$ 山本 泰 次*
塩 野 剛 司** 西川 友 三**

The Degradation Depth of Y-TZP Specimens

by Aging at Low Temperatures

by

\author{
Ryoichi Shikata*, Taiji Yamamoto*, Takeshi Shiono** \\ and Tomozo NishikaWA**
}

The mechanical properties of yttria-doped tetragonal zirconia polycrystals (Y-TZP) are known to be degraded by aging at $100 \sim 300^{\circ} \mathrm{C}$ in air due to tetragonal to monoclinic phase transformation. In the present study, hot-water aging tests were done for several Y-TZP specimens having different grain size which were made from raw powders with different specific surface area. The tetragonal to monoclinic phase transformation zone depth from the surface after the hot-water aging was measured by a thin film X-ray diffraction method, by which the small amount of transformed monoclinic phase existing very close to the surface can be detected.

Y-TZP with the small grain size of $0.15 \mu \mathrm{m}$, made by firing at $1300^{\circ} \mathrm{C}$ for 3 hours using zirconia raw powder with specific surface area of $30 \mathrm{~m}^{2} / \mathrm{g}$, showed only a small amount of transformed monoclinic phase even by $200^{\circ} \mathrm{C}$ hot-water aging for 100 hours. Furthermore, its phase transformation depth was only $2.3 \mu \mathrm{m}$ and the depth did not increase even after a more prolonged aging time.

Key words : Zirconia, Degradation, Degradation layer thickness, Y-TZP, Thin film X-ray diffraction, Raw powder

\section{1 は じめに}

正方晶ジルコニア多結晶体 (TZP) は, 高強度か つ高じん性を有する材料である. なかでも， $\mathrm{Y}_{2} \mathrm{O}_{3}$ を 固溶した Y-TZP は，優れた機械的性質を有すると ともに焼結も比較的しやすいという利点をもち，実用 の機械材料として最も期待されている材料の一つであ る. TZP の機械的性質の優秀さは, 製造過程で高温 安定相である正方晶ジルコニアが室温まで準安定の状 態で保持され，破壊に際してこの正方晶ジルコニアが クラック先端の応力場において単斜晶ヘマルテンサイ 卜型恋態をすることによると考えられている．しかし， このように室温では高強度かつ高じん性をしめす $\mathrm{TZP}$ も，100 300 $\mathrm{C}$ の比較的低い温度領域で, 準安 定状態にある正方晶がより安定な単斜晶へ相転移を起 こし，その結果強度が低下寸るという現象（以下熱劣 化という）があり，その実用的用途開発の大きな障害 となっている．この TZP の熱劣化にたいしては，ジ ルコニア焼結体中の正方晶粒子の粒径, 安定化剤の種 類と量, 焼結体の密度や微細構造等が影響するものと 考えられている。 またた，その熱劣化は，水の存在が
$\mathrm{ZrO}_{2}$ と $\mathrm{H}_{2} \mathrm{O}$ との化学反応による $\mathrm{Zr}-\mathrm{O}-\mathrm{Zr}$ 結合の 切断甬 $8 \mathrm{Y}(\mathrm{OH})_{3}$ の生成等を引き起こし, 正方晶から単 斜晶への相転移を促進させると報告されている．しか し，この熱劣化が，焼結体表面からどのように焼結体 内部に進展するかについての報告はほとんどなされて いない. ジルコニアの正方晶から単斜晶への相転移深 さは, X 線回折によって推定する方法が提案されて いるが, ここでは, 主として薄膜 $\mathrm{X}$ 線回折装置を用 いて，Y-TZP の極く表面に近い部分における，熱劣 化深さの推定を試みた．同時に, $\mathrm{Y}-\mathrm{TZP}$ の熱劣化を 改善するための基礎的知見を得るために，ジルコニア 焼結体の製造条件と，それによって決まる微構造特に 焼結体の結晶粒径が，熱劣化深さに及ぼす影響につい て検討した。

\section{2 実 験 方 法}

\section{$2 \cdot 1$ ジルコニア原料粉末の作製}

ジルコニア原料粉末の作成の方法は, 基本的には著 者らの既報と同一であった，すなわち，試薬特級酸塩 化ジルコニウム $\left(\mathrm{ZrOCl}_{2} \cdot 8 \mathrm{H}_{2} \mathrm{O}\right)$ と $\mathrm{NH}_{4} \mathrm{OH}$ から生 成した水酸化ジルコニウム $\left(\mathrm{Zr}(\mathrm{OH})_{4}\right)$ に, 酸塩化ジ

$\dagger \quad$ 原稿受理 平成元年11月17日 Received Nov. 17, 1989

* 大阪セメント(株) 大阪市大正区南恩加島, Osaka Cement Co. Ltd., Minamiokajima, Taisho-ku, Osaka

** 正会員 京都工芸緎維大学 京都市左京区松ヶ崎御所海道町, Kyoto Institute of Technology, Goshokaido-cho, Matsugasaki, Sakyo-ku, Kyoto 
ルコニウムをモル比 $7: 3$ で加えてスラリー状とし, 常圧沸騰下で 5 日間保持し水和ジルコニアを作った. この水和ジルコニア溶液に, 試薬特級塩化イットリウ 厶 $\left(\mathrm{YCl}_{3} \cdot 6 \mathrm{H}_{2} \mathrm{O}\right)$ 溶液を 3 モル \% 加えて混合後， か く拌しながらアンモニア水を加えて共沈させ，乃過・ 洗浄を繰り返した.この共沈物質から，種々の比表面 積をもった Y-TZP 原料粉末を得るために,これを 乾燥後, 電気炉で $800^{\circ} \mathrm{C}, 950^{\circ} \mathrm{C}, 1100^{\circ} \mathrm{C}$ で仮焼し, 解砕・粉砕して, それぞれ比表面積約 10，20，30 $\mathrm{m}^{2} / \mathrm{g}$ をつジルコニア原料粉末を作った. 得られた ジルコニア原料粉末の詳細な化学成分, 比表面積, 結 晶子径は, 既報に示した通りである.

\section{$2 \cdot 2$ 試験片の作成}

ジルコニア原料粉末を成形圧 $39 \mathrm{MPa}$ で金型に よって子備成形した後, $500 \mathrm{MPa}$ で CIP 成形し, 直 径 $65 \mathrm{~mm}$, 厚さ $4 \mathrm{~mm}$ の円板状の生成形体を作成し た. 比表面積の異なるジルコニア原料粉末から密度 $6.0 \mathrm{~g} / \mathrm{cm}^{3}$ 以上の焼結体を作成するために，既報の結 果を参考にして，比表面積 $30 \mathrm{~m}^{2} / \mathrm{g}$ の原料粉末から 作成した生成形体は $1300^{\circ} \mathrm{C}, 20 \mathrm{~m}^{2} / \mathrm{g}$ のものは $1400^{\circ} \mathrm{C}, 10 \mathrm{~m}^{2} / \mathrm{g}$ のものは $1500^{\circ} \mathrm{C}$ で，それぞれ 3 時 間焼成した。

Table I. Bulk density of sintered bodies and conditions of firing temperature and raw powder.

\begin{tabular}{l|c|c}
\hline Raw powder & $\begin{array}{c}\text { Firing } \\
\text { conditions }\end{array}$ & $\begin{array}{c}\text { Bulk density of } \\
\text { sintered body }\end{array}$ \\
\hline $10 \mathrm{~m}^{2} / \mathrm{g}$ & $1500^{\circ} \mathrm{C}, 3 \mathrm{hr}$ & $6.03 \mathrm{~g} / \mathrm{cm}^{3}$ \\
\hline 20 & 1400,3 & 6.05 \\
\hline 30 & 1300,3 & 6.02 \\
\hline
\end{tabular}

Table Iに，得られた焼結体の密度を示す，それぞ れすべてが密度 $6.0 \mathrm{~g} / \mathrm{cm}^{3}$ 以上を示し，充分に焼き 締まった焼結体が得られていることがわかる．これら の焼結体から試験片を作成するために，焼結体をダイ ヤモンドホイル（\#200，\#800）で研削し，ダイヤモ ンドペースト $(10 \mu \mathrm{m}, 0.25 \mu \mathrm{m})$ で十分にラッピン グ後, 切断して縦 $10 \mathrm{~mm}$, 横 $10 \mathrm{~mm}$, 厚さ $3 \mathrm{~mm}$ の 試験片とした.

\section{$2 \cdot 3$ 熱劣化条件と熱劣化の評価}

熱処理は, 熱劣化が最も進展しやすく, かつ短時間 に評価できると考えられる $200^{\circ} \mathrm{C}$ 熱水中で行なった。 この条件で試験片を所定時間熱水処理し, 正方晶から 相転移して生成する単斜晶量によって, 熱劣化を評価 した. 熱水処理で生成した単斜晶量は, $\mathrm{X}$ 線回折に よって式(1)より求めた.

$$
\begin{gathered}
V_{m}=\frac{\mathrm{I}_{m}(111)+\mathrm{I}_{m}(11 \overline{1})}{\mathrm{I}_{m}(111)+\mathrm{I}_{m}(11 \overline{1})+\mathrm{I}_{t}(111)} \\
V_{m}: \text { 単斜晶量の体積分率 }
\end{gathered}
$$

$\mathrm{I}:$ 各反射面の積分強度

添字 $m, \quad t$ : それぞれ単斜晶および正方晶

また, $200^{\circ} \mathrm{C}$ 熱水処理前の試験片中には，単斜晶が 含まれていないことをあらかじめ X 線回折によって 確認しておいた.

\section{$2 \cdot 4$ 熱劣化深さの推定}

$200^{\circ} \mathrm{C}$ 熱水中で，所定時間処理した後の試料表面か らの熱劣化深さ（単斜晶への変化が起こった深さ）は, 熱劣化層が $10 \mu \mathrm{m}$ 以上の深い試料（熱劣化の比較的 進んだ試料）に対してはダイヤモンドホイールによる 研削法で, 熱劣化層が $10 \mu \mathrm{m}$ 以下の浅い試料（熱劣 化のあまり進んでいない試料）に対しては薄膜 $\mathrm{X}$ 線 回折法により推定した. 研削法と薄膜 X 線回折法に よる熱劣化深さの測定は，次に示す通りである.

2・4・1 研削法 試料表面をダイヤモンドホイー ルで研削しながら，それぞれの研削段階で X 線回折 を行い, 単斜晶が認められなくなるまでこれを繰り返 し, 単斜晶が認められなくなった研削量を熱劣化深さ とした.ここでの研削条件は, ダイヤモンド砥粒 \# 800 , 切込み深さ $1 \mu \mathrm{m}$ とし, あらかじめこの研削に よっては正方晶から単斜晶への相転移が認められない ことを確認しておいた。

$2 \cdot 4 \cdot 2$ 薄膜 $X$ 線回折法 薄膜 $X$ 線回折装置 （リガク TFD）を用いて， $\mathrm{X}$ 線入射角を $0.5 \sim 15^{\circ}$ の 範囲で变化させ回折を行ない, 式 (1)よりX 線入射角 に対応した分析深さごとの単斜晶量を計算し, 単斜晶 が認められなくなる深さを求めて正方晶より単斜晶へ の相転移深さ, すなわち熱劣化深さとした．ここで使 用した薄膜 $\mathrm{X}$ 線回折の条件は，管球 $\mathrm{Cu}$, 電圧 $60 \mathrm{kV}$, 電流 $200 \mathrm{~mA}$, DS $0.4 \mathrm{~mm}$, 走査速度 $2 \% / \mathrm{min}$, サン プリング幅 $0.02 \circ$ であった.

薄膜 X 線回折法の概要を Fig. 1 に示す。この薄膜 $\mathrm{X}$ 線回折装置では，回転式対㓌極を用いた $\mathrm{X}$ 線発生 装置より，小さな入射角で試料表面に入射させ， $\mathrm{X}$ 線の侵入深さを極力浅くして，表面分析を可能として いる. 測定に際しては，X 線入射角と試料を固定し， 検出器のみが試料中心に走査する. このとき回折に関 与する試料の有効厚さ $(t)$ は,

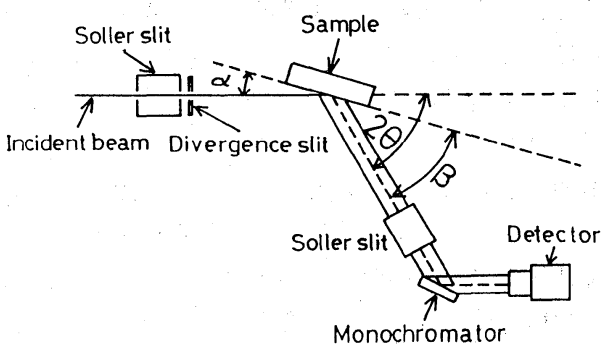

Fig. 1. Schematic illustration of thin film $\mathrm{X}$-ray diffractometer. 
Table II. X-ray incident angle and effective penetration depth of $\mathrm{X}$-ray at zirconia sintered body containing $3 \mathrm{~mol} \% \mathrm{Y}_{2} \mathrm{O}_{3}$.

\begin{tabular}{l|c|c|c|c|c|c}
\hline Incident angle of X-ray $\left({ }^{\circ}\right)$ & 0.5 & 1.0 & 2.0 & 5.0 & 10.0 & 15.0 \\
\hline Effective penetration depth $(\mu \mathrm{m})$ & 0.6 & 1.2 & 2.3 & 5.1 & 8.1 & 9.1 \\
\hline
\end{tabular}

$$
\begin{aligned}
R_{t}= & \frac{\int_{t=0}^{t=t} d \mathrm{I}_{D}}{\int_{t=0}^{t=\infty} d \mathrm{I}_{D}} \\
& =1-\exp \left\{-\mu t\left(\frac{1}{\sin \alpha}+\frac{1}{\sin \beta}\right)\right\}
\end{aligned}
$$

$R_{t}$ : 十分厚い試料と厚さ $t$ の薄膜から得られる回 折強度比

$\mathrm{I}_{D}:$ 単位面積当りの回折強度

$\mu:$ 試料の線吸収係数

$\alpha$ : 試料表面と入射 $\mathrm{X}$ 線とのなす角

$\beta$ : 試料表面と回折 $\mathrm{X}$ 線とのなす角 $(2 \theta-\alpha)$ より,

$$
t=-\frac{\sin \alpha \cdot \sin \beta \cdot l_{n}\left(1-R_{t}\right)}{\mu(\sin \alpha+\sin \beta)}
$$

と計算される。 こ

$$
\mu / \rho=W_{A} \cdot(\mu / \rho)_{A}+W_{B} \cdot(\mu / \rho)_{B}
$$

$\mu / \rho:$ 質量吸収係数

$W:$ 元素の重量比

添字 $A, B$ : 元素 $\mathrm{A}, \mathrm{B}$

である，上述の関係をもとに，本実験に用いた 3 モル $\%$ の $\mathrm{Y}_{2} \mathrm{O}_{3}$ を含む $\mathrm{Y}-\mathrm{TZP}$ の線吸収係数 $(\mu)$ は, 式 (3) より $0.0653 \mu \mathrm{m}^{-1}$ となる. さらに, $\mu$ は正方晶, 単斜 晶によらず一定， $R_{t}=0.99,2 \theta=30^{\circ}$ として，式 (2) を用いて X 線分析深さを計算した結果を, Table II に示す.

\section{3 実験結果と考察}

\section{$3 \cdot 1$ 熱劣化による単斜晶量の経時変化}

$2 \cdot 2$ 節で作った 3 種のジルコニア焼結体の, $200^{\circ} \mathrm{C}$ 熱水処理による単斜晶量の増加の時間変化を Fig. 2 に 示す.この場合の単斜晶量は, 通常の X 線回折法に よって $2 \theta$ を約 $30^{\circ}$ として測ったもので, Table II に 示したように有効 $\mathrm{X}$ 線侵入深さは $9.1 \mu \mathrm{m}$ とかなり深 い部分までの分析結果である. また， $200^{\circ} \mathrm{C}$ 熱水処理 前には，これらのジルコニア焼結体の結晶相は正方晶 のみで, 単斜晶は認められていない. Fig. 2 から 3 種 のジルコニア焼結体の間で, 熱水処理による単斜晶量 の増加すなわち熱劣化の進行に, 大きな違いがあるこ とがわかる. またFig. 3 には，これら 3 種のジルコニ ア焼結体の平均結晶粒子径の大きさを示した．焼結体 の平均結晶粒径は, 試験片を沸騰リン酸中でエッチン グし, SEM 写真での平均切片長さから求めた。. Fig. 2 と Fig. 3 の対比は, 比表面積 $30 \mathrm{~m}^{2} / \mathrm{g}$ のジルコニア
原料粉末を $1300^{\circ} \mathrm{C}$ で 3 時間焼成して得られた最も平 均結晶粒径の小さい焼結体で，熱劣化がまったく起 こっていないことを教えている．また，一般的に言っ て平均結晶粒径の小さい焼結体ほど，熱水処理による 劣化が少ないということもこれらの図が示している.

\section{$3 \cdot 2$ 研削法による熱劣化深さ}

Fig. 2 に示したように, $200^{\circ} \mathrm{C}$ 熱水処理にようて焼 結体表面の正方晶が $65 \%$ も単斜晶に変化した焼結体 （比表面積 $10 \mathrm{~m}^{2} / \mathrm{g}$ のジルコニア原料粉末を, $1500^{\circ} \mathrm{C}$ で 3 時間焼成して得られた焼結体）では，相転移はか なり内部まで進行していると考えられるため，2・4・ 1 項の研削法によって, 表面からの相転移量の変化を 調べた. その変化の状況を Fig. 4 に示す. $200^{\circ} \mathrm{C}$ 熱水 処理が 3 時間のものでは相転移は表面から約 $40 \mu \mathrm{m}$ 深さまで進行し, $200^{\circ} \mathrm{C}$ 熱水処理が 5 時間のものでは 相転移は表面から約 $90 \mu \mathrm{m}$ 深さまで進んでいること がわかる，相転移は，時間とともに内部まで進行する わけである.この相転移の内部への進行の過程は, 表 面の正方晶粒子が単斜晶に変態し，その変化に基づく 体積膨張によって焼結体表面近くにクラックが発生し, そのクラックを通って熱水が内部に浸透して内部の正 方晶を単斜晶に変態させていく．その過程を繰り返す ものと考えられる.このような現象は, 比表面積 10

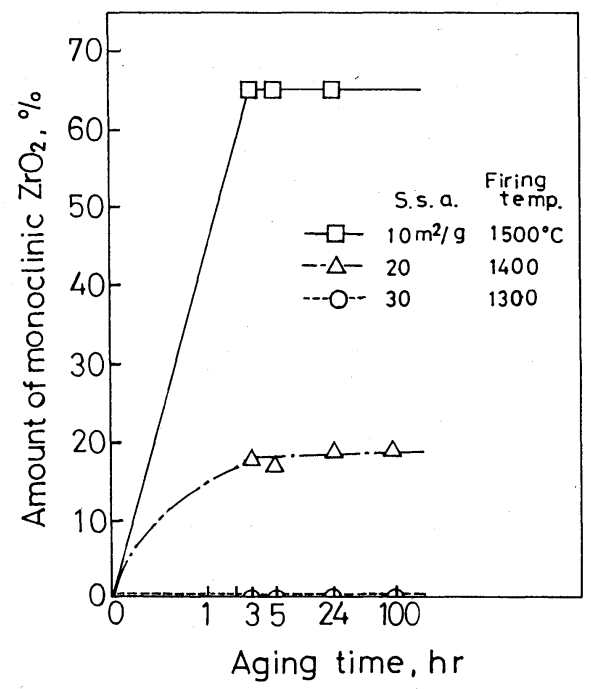

Fig. 2. Change in the amount of monoclinic phase of zirconia sintered bodies obtained from different firing temperature and specific surface area of raw powder by aging in hot water of $200^{\circ} \mathrm{C}$. 


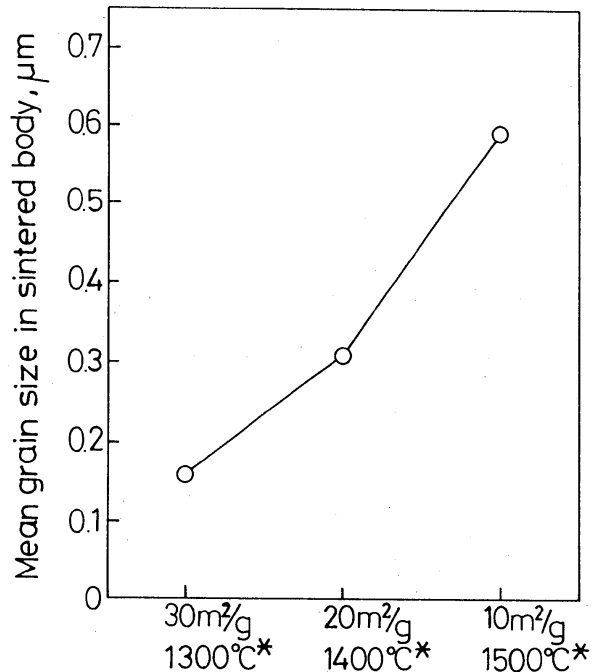

Specific surface area of raw powder

* Firing temperature

Fig. 3. Influences of specific surface area of raw powder and firing temperature on mean grain size in sintered body.

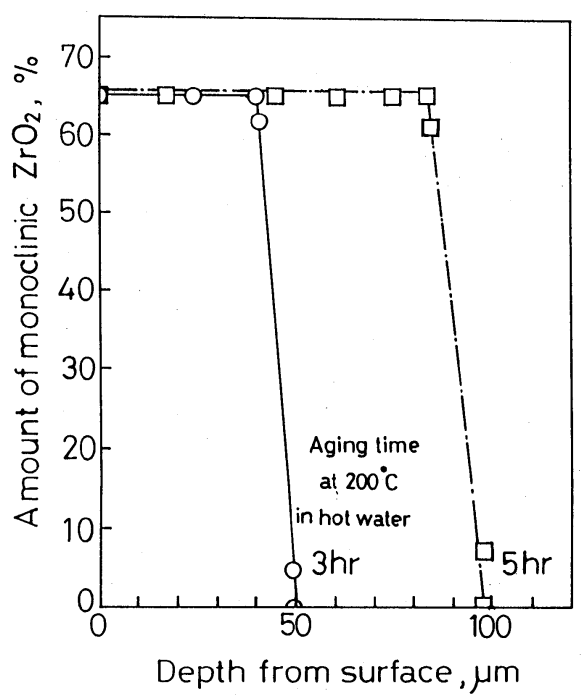

Fig. 4. Degradation depth of $1500^{\circ} \mathrm{C}$ sintered body obtained from the raw powder of specific surface area $10 \mathrm{~m}^{2} / \mathrm{g}$ by grinding method.

$\mathrm{m}^{2} / \mathrm{g}$ 粉末の $1500^{\circ} \mathrm{C}$ 焼結体において, 正方晶粒子が 大きく成長したことや，多くの粒子が同時に正方晶か ら単斜晶に相転移したことによって，促進されたもの と考えられる.

\section{$3 \cdot 3$ 薄膜 $\mathrm{X}$ 線回折法による熱劣化深さ}

$200^{\circ} \mathrm{C}$ 熱水処理による熱劣化が少ない，すなわち熱 劣化層が $\mathrm{X}$ 線回折分析深さよりも浅いと考えられる 焼結体（比表面積 $20,30 \mathrm{~m}^{2} / \mathrm{g}$ のジルコニア原料粉 末を，それぞれ $1400 ， 1300$ で 3 時間焼成して得られ

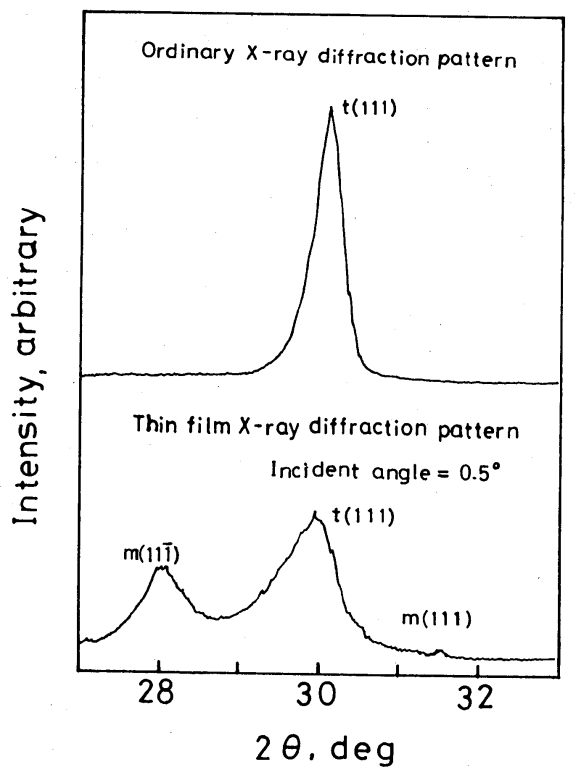

Fig. 5. Comparison between ordinary X-ray diffraction pattern and thin film $\mathrm{X}$-ray diffraction pattern of $1300^{\circ} \mathrm{C}$ sintered body obtained from the raw powder of specific surface area $30 \mathrm{~m}^{2} / \mathrm{g}$ by aging in hot water of $200^{\circ} \mathrm{C}$ for 24 hours.

た焼結体）については，薄膜 $\mathrm{X}$ 線回折法によって低 温熱劣化深さを推定した. 薄膜 $\mathrm{X}$ 線回折法が熱劣化 深さの浅いものに有効であることを示すために, Fig. 5 に通常の X 線回折による回折図形々薄膜 X 線回折 による回折図形を比較して示した．測定試料は，比表 面積 $30 \mathrm{~m}^{2} / \mathrm{g}$ 粉末の $1300^{\circ} \mathrm{C}$ で焼結体を, $200^{\circ} \mathrm{C}$ 熱水 中で 24 時間熱处理したものである. 通常の X 線回折 では認められない単斜晶の (111) 面や (111) 面の回折 ピークが, $\mathrm{X}$ 線入射角 $0.5^{\circ}$ の薄膜 $\mathrm{X}$ 線回折によって はっきり確認できる.

Fig. 6 には, 比表面積 $20 \mathrm{~m}^{2} / \mathrm{g}$ 粉末の $1400^{\circ} \mathrm{C}$ 焼結 体, 拉よび比表面積 $30 \mathrm{~m}^{2} / \mathrm{g}$ 粉末の $1300^{\circ} \mathrm{C}$ 焼結体に ついて, $200^{\circ} \mathrm{C}$ 熱水中で $5 \sim 100$ 時間処理した場合の 表面単斜晶量の変化を, 薄膜 $\mathrm{X}$ 線回折装置を用いて $\mathrm{X}$ 線入射角を变えて測定した結果を示す，これより， 熱劣化深さを推定する一例として, 比表面積 $30 \mathrm{~m}^{2} / \mathrm{g}$ 粉末の $1300^{\circ} \mathrm{C}$ 焼結体を, $200^{\circ} \mathrm{C}$ 熱水中で 100 時間处 理した場合 (Fig. 6 上部 $\square$ 印)について述べる.X 線入射角 $0.5^{\circ}$ での単斜晶量が $29.2 \%$ というのは, 試 料表面より $0.6 \mu \mathrm{m}$ 深さまでは平均単斜晶量が $29.2 \%$ であることを意味し, $\mathrm{X}$ 線入射角 $1.0^{\circ}$ での単斜晶量 が $23.2 \%$ というのは, 試料表面より $1.2 \mu \mathrm{m}$ 深さまで は平均単斜晶量が $23.2 \%$ であることを意味している. したがって, 深さ $0.6 \mu \mathrm{m}$ から $1.2 \mu \mathrm{m}$ の間の部分に 抒ける平均単斜晶量 (M\%) は, 
Effective penetration depth; $\mu \mathrm{m}$

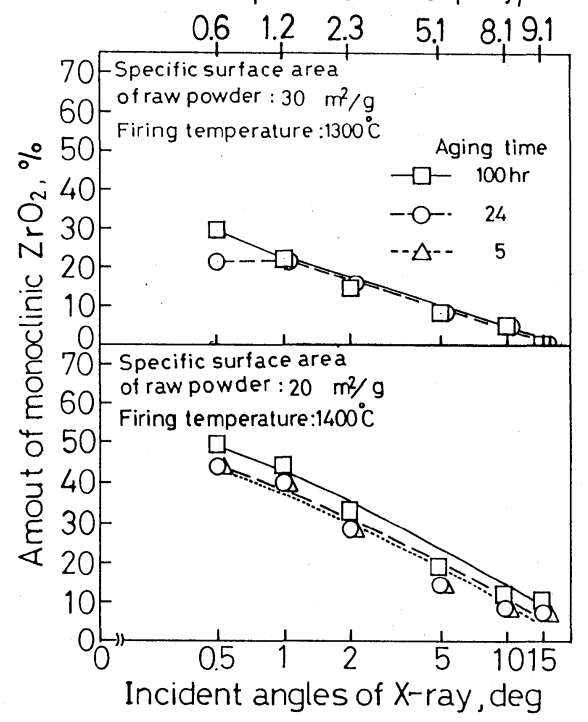

Fig. 6. Relation between incident angle of X-ray and the amount of monoclinic phase of 1300 and $1400^{\circ} \mathrm{C}$ sintered bodies obtained from the raw powders of specific surface area 30 and $20 \mathrm{~m}^{2} / \mathrm{g}$ respectively by aging in hot water of $200^{\circ} \mathrm{C}$ for $5 \sim 100$ hours.

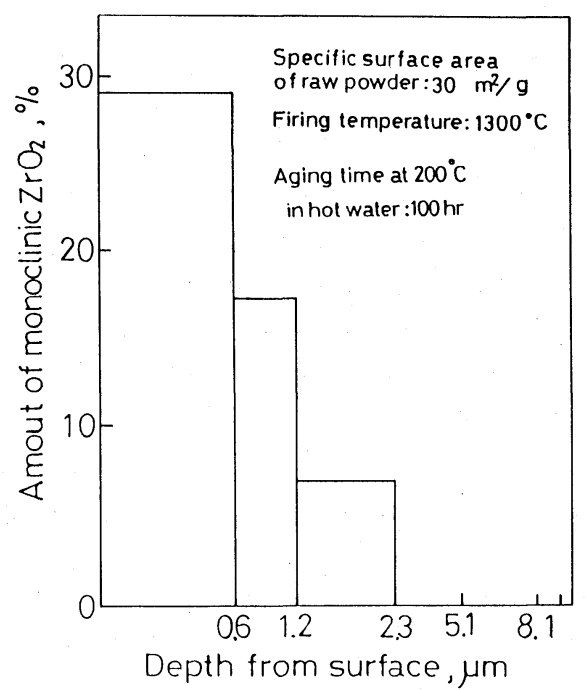

Fig. 7. Relation between the depth from surface and the amount of monoclinic phase of $1300^{\circ} \mathrm{C}$ sintered body obtained from the raw powder of specific surface area $30 \mathrm{~m}^{2} / \mathrm{g}$ by aging in hot water of $200^{\circ} \mathrm{C}$ for 100 hours.

$$
\begin{aligned}
& \frac{(0.6-0) \mu \mathrm{m}}{1.2 \mu \mathrm{m}} \times 29.2 \%+\frac{(1.2-0.6) \mu \mathrm{m}}{1.2 \mu \mathrm{m}} \times \mathrm{M} \% \\
& \quad=23.2 \%
\end{aligned}
$$

から計算され， $17.2 \%$ となる．同様にして，入射角 $2.0^{\circ}$ 抢よび入射角 $5.0^{\circ}$ での単斜晶量を用いて計算す ることにより, 深さ $1.2 \sim 2.3 \mu \mathrm{m}$ の間の部分における

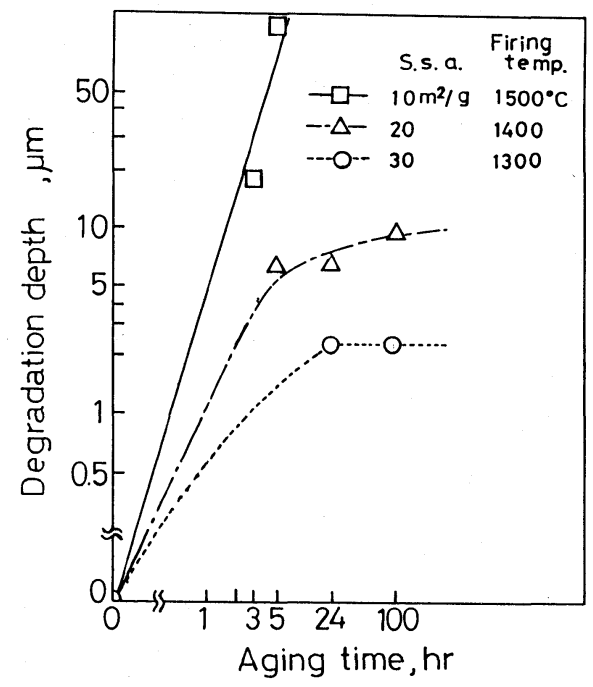

Fig. 8. Time dependence of degradation depth in zirconia sintered bodies obtained from different firing temperature and specific surface area of raw powder by aging in hot water of $200^{\circ} \mathrm{C}$.

平均単斜晶量は $7.3 \%$, 深さ $2.3 \sim 5.1 \mu \mathrm{m}$ の間の部分 における平均単斜晶量は $0 \%$ となる。このようにし て得られた単斜晶量と表面からの深さの関係を Fig. 7 に示した.これより, 比表面積 $30 \mathrm{~m}^{2} / \mathrm{g}$ の粉末を用 いて $1300^{\circ} \mathrm{C}$ で焼成して得られた焼結体では, $200^{\circ} \mathrm{C}$ 熱水中で 100 時間処理しても, 正方晶から単斜晶への 相転移は表面からわずかに $2.3 \mu \mathrm{m}$ 深さまでしか起 こっていないと考えられる.

このようにして, Fig. 6 で得られた $\mathrm{X}$ 線入射角と単 斜晶量の関係から, 表面からの熱劣化深さを求め, $200^{\circ} \mathrm{C}$ 熱水处理時間との関係で示したのが, Fig. 8 で ある.なお, Fig. 8 には, 比表面積 $10 \mathrm{~m}^{2} / \mathrm{g}$ 粉末の $1500^{\circ} \mathrm{C}$ 焼結体の熱劣化深さを, 前述の研削法によっ て求めた結果もあわせて示した. $200^{\circ} \mathrm{C}$ 熱水処理によ る劣化が少なかった比表面積 $30 \mathrm{~m}^{2} / \mathrm{g}$ 粉末の $1300^{\circ} \mathrm{C}$ 焼結体は, 平均結晶粒径が $0.15 \mu \mathrm{m}$ と小さいにもか かわらず, 表面から深さ的 $2.3 \mu \mathrm{m}$ のとこまで熱劣 化が進んでいた．すでに報告されていてる，これ以上結 晶粒子が小さければ熱劣化が起こらないという，いわ ゆる臨界粒子径は 0.3 0.4 $\mu \mathrm{m}$ であり，ここでの実験 結果は, それより小さい結晶粒子であっても, 表面に 损いては正方晶から単斜晶への相転移が起こっている ことを示している. これは, 正方晶粒径が臨界粒子径 以下であっても, 表面での正方晶中の何らかの欠陥が 核になり, 正方晶から単斜晶への相転移を引き起こし たものと考えられる. しかし, この焼結体に扔いて正 方晶粒子は小さく，かつマトリックスによる拘束効果 も作用することから， $200^{\circ} \mathrm{C}$ 熱水中で $24 \sim 100$ 時間処 理しても熱劣化は深さ方向に進展せず，表面から極く 
浅い部分にのみとどまるということになる．

比表面積 $20 \mathrm{~m}^{2} / \mathrm{g}$ の粉末を $1400^{\circ} \mathrm{C}$ で焼成して得ら れた焼結体では, $200^{\circ} \mathrm{C}$ 熱水中での熱劣化深さは, 比 表面積 $30 \mathrm{~m}^{2} / \mathrm{g}$ の粉末を $1300^{\circ} \mathrm{C}$ で焼成して得られた 焼結体より，熱劣化深さはいくぶん深くなるとともに， $200^{\circ} \mathrm{C}$ 熱水処理 100 時間以降も熱劣化はさらに進展す る可能性を示した.これは，Fig. 3 に示した焼結体の 結晶粒径に関連しているものと考えられる.

以上, 比表面積が大きく比較的低い温度で焼結可能 なジルコニア粉末を用いて, $1300^{\circ} \mathrm{C}$ で焼成して得ら れたジルコニア焼結体は, $200^{\circ} \mathrm{C}$ 熱水中での加速熱劣 化試験において，表面より深さ $2 \mu \mathrm{m}$ 程度までのわず かな熱劣化を示すに過ぎず，しかも，その後の熱劣化 の進展は見られないすぐれた耐熱劣化材料であると言 うことができる。

$$
4 \text { ま め }
$$

加水分解法によって， 3 モル\%の $\mathrm{Y}_{2} \mathrm{O}_{3}$ を含むジル コニア原料粉末を合成し，その比表面積と焼成温度を 変えて, 約 $0.15,0.3,0.6 \mu \mathrm{m}$ の結晶粒径を有する正 方晶ジルコニア多結晶体を作製した.これらのジルコ ニア焼結体を $200^{\circ} \mathrm{C}$ 熱水中で処理して, 正方晶から 単斜晶への相転移深さを, X 線回折法および薄膜 $\mathrm{X}$ 線回折法等を用いて測定し, 以下に示す結論を得た.

（1）試料表面の熱劣化は，結晶粒径が $0.15 \sim 0.3$ $\mu \mathrm{m}$ と小さい Y-TZP 焼結体では熱劣化層が浅く, 通 常の X 線回折法では十分に検出できない. そのよう な場合には，薄膜 X 線回折による分析は非常に有効 であり，X 線入射角を変えながら単斜晶量を定量し ていくことによって，表面から極く浅い部分における 熱劣化深さを推定できた.

（2）熱劣化深さには，原料粉末の比表面積と焼成温 度によって決まる焼結体の正方晶粒径が，大きな影響 を及ぼしていた。

（3）比表面積 $30 \mathrm{~m}^{2} / \mathrm{g}$ の原料粉末を $1300^{\circ} \mathrm{C}$ で 3 時 間焼成して得られた焼結体においては，通常の $\mathrm{X}$ 線 回折では， $200^{\circ} \mathrm{C}$ 熱水処理による熱劣化は，まったく 認められなかった。一方, 薄膜 X 線回折によると, 表面から約 $2 \mu \mathrm{m}$ 深さまでの熱劣化層の存在が認めら れたが, 熱水処理時間を増やしてもそれ以上の熱劣化 の進展は認められなかった. 比表面積の大きい原料粉 末 $\left(30 \mathrm{~m}^{2} / \mathrm{g}\right)$ を比較的低い温度 $\left(1300^{\circ} \mathrm{C}\right)$ で焼成す ることによって，Y-TZP の熱劣化が著しく改善され
ることがわかった.

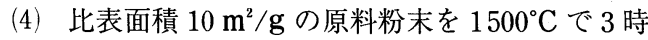
間焼成して得られた焼結体は，大きな結晶粒子で構成 され，その熱劣化深さは $200^{\circ} \mathrm{C}$ 熱水処理時間に比例 して進行し, 100 時間で焼結体は崩壊した.

\section{参 考 文 献}

1 ) K. Kobayashi, H. Kuwajima and T. Masaki, Solid State Ionics, 3/4, 489 (1981).

2 ) M. Matsui, T. Soma and I. Oda, Advances in Ceramics, 12, 371 (1984)

3) M. Watanabe, S. Iio and I. Fukuura, Advances in Ceramics, 12, 391 (1984)

4 ) K. Tsukuma, Y. Kubota and T. Tsukidate, Advances in Ceramics, 12, 382 (1984)

5 ) T. Takahata and K. Tsukuma, "Zirconia Ceramics", 9, 13 (1987) Uchida Rokakuho

6 ) T. Soma, "Zirconia Ceramics", 9, 37 (1987) Uchida Rokakuho

7 ) T. Sato and M. Shimada, J. Am. Ceram. Soc., 68, 6, 356 (1985).

8 ) M. Yoshimura, T. Noma, K. Kawabata and S. Somiya, Zirconia Ceramics, 9, 73 (1987) Uchida Rokakuho

9 ) F. Flange, G. L. Dunlop and B. I. Davis, J. Am. Ceram. Soc., 69, 3, 237 (1986).

10) K. Nakajima and T. Masaki, Zirconia Ceramics, 9, 27 (1987) Uchida Rokakuho

11) T. Kosmac, R. Wagner and N. Claussen, J. Am. Ceram. Soc., 64, c-72 (1981).

12) R. C. Garvie, R. H. J. Hannink and M. V. Swain, J. Mater. Sci. Letters, 1, 437 (1982).

13）四方良一, 山本泰次, 西川友三, 材料, 39, 759 (1990).

14) T. Arai, T. Yamamoto and K. Tsuji, "Extended Abstract Zirconia '86 Tokyo", p. 338 (1986) The Ceramic Society of Japan

15) R. C. Garvie and P. S. Nicholson, J. Am. Ceram. Soc., 55, 6, 303 (1972).

16) The Rigaku-Denki Journal, 16, 15 (1985) 理学電機

17）片山道雄, 清水真人, 第23回 $\mathrm{X}$ 線分析討論会要旨集, p. 29 (1986).

18）B. D. Cullity（松村訳)，“X 線回折要論”, p. 472 (1985) アグネ

19）山口 喬, 柳田博明, 水谷惟恭, 尾崎義治, 木村敏夫, “セラミックプロセシング”, p. 194 （1985）技報堂出版 